\title{
AMSS Third Regional Conference
}

\author{
Arlington, TX - August 23, 2003
}

At its Third Regional Conference, the AMSS broke new ground, dispelling the popular image that Muslims are extremists and Islam is engaged in holy war against the West. Mayor Robert Cluck welcomed the participants, praised American Muslim organizations' condemnation of 9/11, and thanked AMSS for informing Americans about Islam and the Muslim contribution to civilization through its publications and annual conventions. MSA president Laith Albataineh welcomed the participants on behalf of the students.

In his introduction, Chairman Basheer Ahmed stated that extremism and terrorism were not unique to a single religion. He exhorted all peaceloving people to unite to rein in extremism before it gets out of control. Congressman Martin Frost (D-Texas), the guest of honor at the luncheon, referred to his post-9/11 statement encouraging every Texan to join him in resisting intolerance and bigotry. While condemning terrorism in the Middle East, he expressed his support for the "roadmap to peace" and a Palestinian state. Congressman Frost is known for his support of civil rights, getting more immigrants into the American armed forces, constituent service, upholding the Bill of Rights, furthering his district's economic development, and assisting students' career development.

Moazam Syed, American Muslim Alliance president elect (Tarrant County) thanked the congressman; said that terror, hatred, and prejudice are alien to all religions; and that: "America will remain just and tolerant, even when confronted with terror and adversity." Bob Ray Sanders, Star Telegram staff writer and columnist, moderated the question and-answer session.

Jamal Badawi (Saint Mary's University, Halifax, Canada) dispelled the inaccurate notions that the Arabic words for "holy war" can be found in the Qur'an, that kufrmeans "infidel," that Allah is the God of Muslims only, that Islam is exclusivistic, and that an unbeliever (kafir) does not have the same right to life as a Muslim, and several other often-misunderstood notions. He affirmed that practice or juristic opinions could not replace the Qur'an and ahadith, advocated an integrative contextual approach toward understanding these texts, and pointed out common pitfalls in their interpretation. His statements were well-received by both Muslims and non-Muslims.

AMSS president Louay Safi analyzed the present extremism found in the Muslim world as being based on distorted interpretations of scripture 
and the lack of free debate on various issues connected with long-standing Islamic practices. Historically, ethnic and religious minorities lived in peace and harmony in the Muslim world, and many of their members occupied important administrative positions at all social and governmental levels. He averred that American Muslims should reenact the old traditions of pluralism, diversity, freedom, and justice for all.

Marc Ellis (Jewish Studies, Baylor University) focused upon the global instability caused by the Israeli-Palestine conflict, where extremists are blamed for the spiral of violence. In their respective diasporas, both Jews and Muslims continue to struggle for identity, status, and empowerment, especially after $9 / 11$. He wondered if the new century would bring even more militancy and violence, or a Jewish-Muslim movement toward justice and compassion.

In his "Theories of the Psychology of Violence," Charles Ballinger (Brite Divinity School, Texas Christian University), stated that 9/11 resulted from Israel's humiliation of the Palestinians and their subsequent reaction, and Osama bin Laden's rivalry with America. He stated that the 9/11 terrorists rebelled against God, who favors a loving, ethical existence and forbids the intentional killing of civilians. Examining how neo-conservatives and right-wing Christian fundamentalists influence the Bush administration's policies, Kamran Bokhari (Howard University) underscored the threat they posed to inter-civilizational dialogue and harmony and explored methods for overcoming these challenges.

Asma Afasaruddin (Notre Dame University) outlined in her paper, "Combating Extremism: Tapping into Islam's Pluralistic Resources," Islam's acceptance of Judaism and Christianity and related that political and historical events had tarnished Islam's tolerant image and thus painted Muslims as ontologically intolerant. After citing the Qur'an's inclusive approach to other faiths, she exhorted Muslims to revert to the pluralistic discourse in the midst of the current paranoia, both among Muslims and non-Muslims. Merve Kavakci (Mason Fellow, Harvard University) outlined a new perspective from a feminine viewpoint: Women's lives are swayed by extremism, reverberating in different societies with different impulses. Underlining extremism's impact on women, she proposed a pragmatic solution.

Apart from Badawi's outstanding keynote address delivered at the banquet, the event was successfully concluded by Dilnawaz Siddiqui's (Clarion University) summation of the sessions. Basheer Ahmed oversaw the lively question-and-answer session that continued until midnight. The two ses- 
sions, attended by an estimated 800 Muslims and non-Muslims, drawn from the entire Metroplex region, received wide media coverage.

Coming after two earlier regional conferences convened by the AMSS southwest chapter, "The Muslim Contribution to Civilization" and "The Role of Religion to Promote World Peace," this latest event was a great success, and one that we expect to lead to more interfaith dialogue.

The conference ended with the issuance of a press release calling for a sustained and long-term effort to defeat terrorism, violence, and many other social problems through dialogue, mutual understanding and tolerance, and replacing war and other forms of violence with nonviolence out of the recognition that every human being is entitled to life, respect, and justice.

The participants agreed that in this rapidly emerging global age, there is a great need to agree upon a minimum set of ethical principles that will determine how we treat each other. In short, we need to develop a global ethic through a consensus-based process of dialogue and then establish it on a firm base so that it can spread further afield and include more people. Such an undertaking is no longer just a nice dream; it has become a necessity.

Ambassador Syed A. Ahsani Member, Muslim Community Center for Human Services Arlington, Texas 